\title{
Is Ptarmica independent genus or attached to Achillea ptarmica, tribe Anthemideae, Asteraceae?
}

\author{
Tsuyoshi Motohashi ${ }^{1}$, Sergey V. Smirnov ${ }^{2}$, Maxim Kucev ${ }^{2}$, Irina V. Tatarenko ${ }^{3}$, \\ Ekaterina D. Tatarenko ${ }^{3}$, K. Svetlana Aleksandrovna, \\ C. Daba Gombocyrenovich ${ }^{4}$ and Katsuhiko Kondo ${ }^{1,5}$
}

\author{
${ }^{1}$ Laboratory of Plant Genetics and Breeding Science, Department of Agriculture, Faculty of Agriculture, \\ Tokyo University of Agriculture, 1737 Funako, Atsugi City, Kanagawa Prefecture, Japan; 243-0034, Japan; \\ ${ }^{2}$ South-Siberian Botanical Garden, Department of Systematic Botany, Faculty of Biology, \\ Altai State University, Barnaul 656099, Russia; ${ }^{3}$ Faculty of Chemistry and Biology, \\ Moscow State Pedagogical University, Moscow; ${ }^{4}$ Department of Botany, \\ Buryat State University, Ulan-Ude 670000, Russia \\ ${ }^{5}$ Author for Correspondence: k3kondo@nodai.ac.jp \\ Received April 15, 2014; accepted May 5, 2014
}

\begin{abstract}
Ptarmica impatiens L.(diploid; 2n=18), P. ledebouri (Heimerl.) Serg.(tetraploid; 2n=36) and P. salicifolia (Bess.) Serg. (tetraploid; $2 \mathrm{n}=36$ ) taxonomically close relatives with and are sometimes placed in the genus Achillea grown commonly in the well northern colder region. The karyotypic comparison showed Ptarmica is somewhat different from Achillea although they were placed in the tribe Anthemideae, the family Asteraceae. Ptarmica should be independent genus separated from Achillea and more meritorious in an ornamental and horticultural purposes.
\end{abstract}

Achillea, commonly called yallow, consists of approximately 100 species and grows naturally throughout Europe, Asia and North America and have been used for medicinal herbs and vegetable (Hieke 1976; Shin and Fu 1983; Bremer and Humphries 1993; Krasnoborov et al.. 2003). Only four to five species of the genus have somewhat gigantic plant forms just like Chrysanthemum with large ligulate flowers named as Achillea ptarmica including large white flowers are commonly distributed in Europe mainly in Scandinavia and Baltic States, Alaska of the U.S.A. most of the places in Canada and a few places in Asia including Japan, Korea and China and Syberian Russia. White, double ligulate-flowered cultivars namely'Pearl Achillea', 'Russian Daisy Seward', 'Alaska August 2002' and so on in Europe and North America are common to horticultural world, Liberty Hyde Bailey Hortorium (1976), although many species of Achillea are found in certain places in Mts. Altai, Altai Republic, Russian Federation, and very weedy in many temperate areas such as Japan and is taxonomically named as Achillea millefolium Ledeb. Thus, some members of Achillea in the Asteraceae, tribe Anthemideae such as A. impatiens L., A. japonica Heimerl, A. ledebourii Heimerl, $A$. ptarmica L., A. salicifolia Besser (=A. cartilaginea Ledeb. ex Reichenb.) and so on (e.g., Bremer and Humphries 1993) can be placed in Ptarmica such as P. impatiens (L.) DC., P. japonica (Heimerl) Vorosch, P. ledebouri (Heimerl.) Serg., P. salicifolia (Bess.) Serg. P. vulgaris Blakw. ex DC. mainly by Russian taxonomists in order 〔Afanasyev and Bochantsev 1961). The genus Achillea / / Flora of the USSR. - Vol. 26. - p. 70-124 (in Russian)] mostly by Russian botanists. Ptarmica and Achillea might cross hybridize with each other and perform such different flower coloration as 'Dwarf Pink Pearl', 'Dwarf Pink
Sneezewort', 'Nana Compacta' 'Red Velvet', red colored 'Terra Cotta', 'Yellow' and so on.

Only a difference between Ptarmica and Achillea is plant sizes; the genus Ptarmica is much taller in stem length than $130 \mathrm{~cm}$, much bigger in leaf size, ray flowers or ligulate flower much bigger just like chrysanthemums. Such cultivars as 'Yallow Pearl', 'Giant Yarrow', 'Giant Gold Yarrow' Achillea Ptarmica L. performs white, multiligulate flowered cultivars such as 'Aunt Stientje', 'Crocus', 'Noblessa', 'Gipi Whit' = 'Gypsy White', 'The Pearl Group' = 'The Pearl', 'Sneeze Wort' and so on. They have quite large ray or ligulate flowers and thus, they are horticulturally very meritorious (Liberty Hyde Bailey Hortorium (1976). These species of Ptarmica have been cytologically well studied mainly in chromosome numbers with the basic chromosome number of $X=9$ mostly by Russian researchers such as Kartashova et al. (1974), Belaeva and Siplivinsky (1975), Sokolovskaya and Probatova (1985), Dmitrieva (1987), Probatova and Sokolovskaya (1990), Lavrenko et al. (1992) and so on, while numerous chromosome data mainly chromosome numbers of Achillea have been reported (Dabrowska 1974; Khandzhyan 1975; Klokov and Kritskaya 1984 Pullariah 1977; Samutina 1978; Tril' 1979 and many others). However, those data of the chromosome numbers reported could not isolate one out of the two genera.

\section{Materials and Methods}

The materials of Ptarmica ledebouri (Heimerl.) Serg. and P. salicifolia (Besser) Serg. cartilaginea (Ledeb. ex Rchb) Tzvelev both approximately ca $1.50 \mathrm{~m}$ tall grew together in rather wet delta area of the river-side in Russian Federation, Tuva Republic, Kakasiya Region, Minusinsk District, near Izykhskie Kopi Village, Abakan River 
Valley; 5333'13'N, 91¹3'75'E, alt. $270 \mathrm{~m}$. When their habitats of the population were observed they were both at the early stage of the flowering season in the middle of August 2010. They showed some flowers but no hybrid flower was recognized. In contast, the plants of $P$. impatiens grew commonly in root-stocks in water as the aquatic plant in the shallow stream in the southeast of Lake Baikal, the Zabaikalsky National Park, Yablonovy Range, Buryat Republic, Russian Federation, where was different in habitats from those of $P$. ledebouri and $P$. salicifolia. However, these three species were grown in hot summer in the greenhouse on Atsugi campus of Tokyo University of Agriculture, and had no flower due to too hot summer.

For a karyotypic comparison, the commonest species of Archillea, dispersed widely all over the temperate to colder zones of the northern hemisphere, A. millefolium L. was collected in Altai Republic: Onguday District, Vicinity of Chuya River, $50^{\circ} 23^{\prime} 86^{\prime \prime} \mathrm{N}$; $86^{\circ} 40^{\prime} 44^{\prime \prime} \mathrm{E}$, alt. $830 \mathrm{~m}$ Ulagan District, ca $29 \mathrm{~km}$ from Aktash to Ulagan. This plant of the species grew together with other Asteraceous species, such as Tanacetum vulgare L.

Growing roots of well grown plants of the three species of Ptarmica and Achillea millefolium were collected and pretreated in $2 \mathrm{mM} 8$-hydroxyquinoline at $18^{\circ} \mathrm{C}$ for $2 \mathrm{~h}$. Then, they were fixed in $45 \%$ acetic acid at $4^{\circ} \mathrm{C}$. They were macerated in the mixture of $1 \mathrm{~N} \mathrm{HCl}$ and $45 \%$ acetic acid $=2: 1$ at $60^{\circ} \mathrm{C}$. Root tips less than $1 \mathrm{~mm}$ long was cut and stained by $1 \%$ aceto-orcein on glass slides for $30 \mathrm{~min}$ in a chamber moistened by $45 \%$ acetic acid. Then, they were covered by cover-slips and were tapped as usual by stick to spread chromosomes in respective cell.

Karyotype formulae of three species of Ptarmica and Achillea millefolium were based on the size data of chromosome characters of ten somatic metaphase cells per species. Position classification of the primary constriction in chromosome followed Levan et al. (1964): Arm ratio was calculated by long arm/short arm; 1.0-1.7 was grouped as median centromere, 3.1-7.0 subterminal centromere, and 7.1 or more terminal centromere.

\section{Results And Discussion}

Fig. 1 shows common white flowers of three species of Ptarmica taken in the natural habitats in Russia: 1. Ptarmica impatiens (L.) DC. taken at the shallow stream in the southeast of Lake Baikal, Lake Baikal, the Zabaikalsky National Park, Yablonovy Range, Buryat Republic, Russian Federation; 2. Ptarmica ledebouri (Heimerl.) Serg. and 3. P. salicifolia both approximately ca $1.50 \mathrm{~m}$ tall grew together in rather wet delta area of the river-side in Russian Federation, Tuva Republic, Kakasiya Region, Minusinsk District, near Izykhskie Kopi Village, Abakan River Valley; 5333'13”N, 91¹3'75'E, alt. 270 m.

The chromosome complements of Ptarmica impatiens, P. ledebouri and P. salicifolia are shown in Fig. 2 (1-3) and their karyotypes are tabulated in Table 1, while the karyotype of Achillea millefolium was $2 \mathrm{n}=36=18 \mathrm{~m}+4 \mathrm{~m}^{\text {sat }}+14 \mathrm{sm}$ (Table 1). Thus, their karyotypes were not the same to each other at the same ploid level and were not proportional to the diploid karyotype.

Species of Ptarmica are mostly tetraploid $(2 \mathrm{n}=36)$ except for only one diploid (Ptarmica impatiens; $2 \mathrm{n}=18$ ), while those of Achillea are varied from diploid $(2 \mathrm{n}=18)$, tetraploid $(2 \mathrm{n}=36)$, pentaploid $(2 \mathrm{n}=45)$, hexaploid $(2 n=54)$ to octoploid $(2 n=72)$ (Index to plant chromosome numbers 1975-2008). The karyotype of Ptarmica impatiens was $2 \mathrm{n}=18=12 \mathrm{~m}+6 \mathrm{sm}$, that of $P$. ledebouri was $2 \mathrm{n}=36=29 \mathrm{~m}+6 \mathrm{sm}+1^{\mathrm{st}}$, and that of $P$. salicifolia was $2 \mathrm{n}=36=29 \mathrm{~m}+1 \mathrm{~m}^{\text {sat }}+5 \mathrm{sm}+1 \mathrm{sm}^{\text {sat }}$ (Table 1; Fig. 2). Those tetraploid karyotypes were somewhat similar to each other. The karyoypes of the three species of Ptarmica were compared with those of Achillea and it was found to be very different from each other (Table 1).

Ptarmica might have been well isolated in colder region and might be more primitive than Achillea. Ptarmica is erect in habit while Achillea is mat-like in

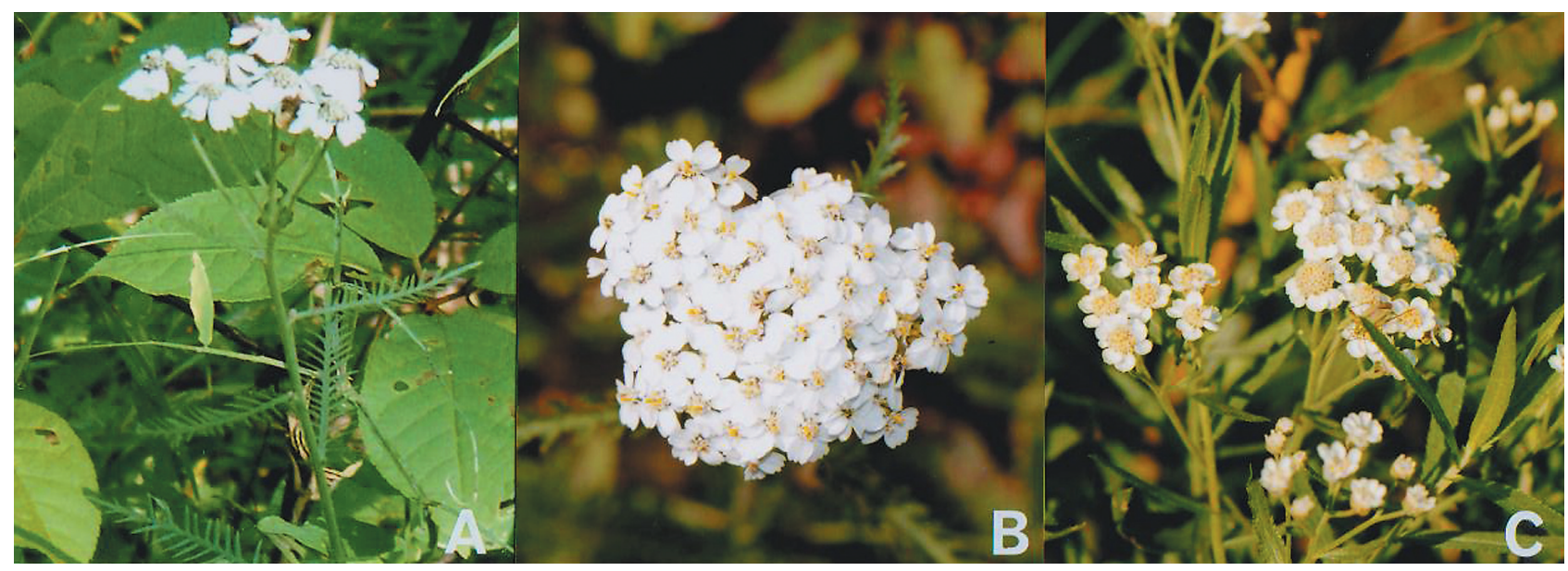

Fig. 1. Flowers of three species of Ptarmica in natural conditions in their native habitats. A. P. impatience L., B. P. ledebouri (Heimerl.) Serg., C. P. salicifolia (Bess.) Serg. cartilaginea (Ledeb.ex Rchb) Tzvelev. 
Table 1. Karyotypes of three species of Ptarmica collected in a certain localities in Siberia, Russia

\begin{tabular}{|c|c|c|}
\hline Species & Karyotype & Locality \\
\hline Achillea millefolium $\mathrm{L}$. & $2 \mathrm{n}=36=18 \mathrm{~m}+4 \mathrm{~m}^{\mathrm{sat}}+14 \mathrm{sm}$ & $\begin{array}{l}\text { Altai Republic: Onguday } \\
\text { District,Vicinity of Chuya } \\
\text { River, } 50^{\circ} 23^{\prime} 86^{\prime \prime} \mathrm{N} \text {; } \\
86^{\circ} 40^{\prime} 44^{\prime \prime} \mathrm{E} \text {, alt. } 830 \mathrm{~m} \\
\text { Ulagan District, ca } 29 \mathrm{~km} \\
\text { from Aktash to Ulagan }\end{array}$ \\
\hline Ptarmica impatiens L. & $2 \mathrm{n}=18=12 \mathrm{~m}+6 \mathrm{sm}$ & $\begin{array}{l}\text { Buryat Republic: } \\
\text { Southeast of Lake Baikal, } \\
\text { The Zabaikalsky National } \\
\text { Park }\end{array}$ \\
\hline P. ledebouri (Heimerl.) Serg. & $2 \mathrm{n}=36=29 \mathrm{~m}+6 \mathrm{sm}+1^{\mathrm{st}}$ & $\begin{array}{l}\text { Tuva Republic: Kakasiya } \\
\text { Region, Minusinsk } \\
\text { District, near Izykhskie } \\
\text { Kopi Village, Abakan } \\
\text { River Valley; } 53^{\circ} 33^{\prime} 13^{\prime \prime} \mathrm{N} \text {, } \\
91^{\circ} 13^{\prime} 75^{\prime} \mathrm{E} \text {, alt. } 270 \mathrm{~m}\end{array}$ \\
\hline $\begin{array}{l}\text { P. salicifolia Bess.Serg. cartilaginea } \\
\text { (Ledeb.ex Rchb) Tzvelev. }\end{array}$ & $2 \mathrm{n}=36=29 \mathrm{~m}+1 \mathrm{~m}^{\mathrm{sat}}+5 \mathrm{sm}+1 \mathrm{sm}^{\mathrm{sat}}$ & $\begin{array}{l}\text { Tuva Republic: Kakasiya } \\
\text { Region, Minusinsk } \\
\text { District, near Izykhskie } \\
\text { Kopi Village, Abakan } \\
\text { River Valley; } 53^{\circ} 33^{\prime} 13^{\prime \prime} \mathrm{N} \text {, } \\
91^{\circ} 13^{\prime} 75^{\prime} \mathrm{E} \text {, alt. } 270 \mathrm{~m}\end{array}$ \\
\hline
\end{tabular}

*The majorty of the monograph papers lists those species as Achillea excepting those listed for the Russian species in the Russian literatures are classed as Ptarmica.



Fig. 2. Chromosome sets of three species of Ptarmica. A. P. impatience L., $2 \mathrm{n}=18$. B. P. ledebouri (Heimerl.) Serg., $2 \mathrm{n}=36$. C. P. salicifolia Bess.Serg. cartilaginea (Ledeb.ex Rchb) Tzvelev., 2n=36. X 600.

habit. Several cultivars of Ptarmica has been horticulturally registered such as 'Angel's Breath', 'Aunt Stientje', 'Crocus', 'Gipi Whit'='Gypsy White' Noblessa', 'The Pearl Group'='The Pearl,', 'Sneeze Wort' mostly white flowers but some pink and yellow and so on. Those horticulturally meritorious plants of Ptarmica have been mostly cultivated in Scandinavia to Baltic areas and to North America down to North Carolina, U.S.A. and so on. Ptarmica was not distinctly but poorly isolated from Achillea.

\section{Literature Cited}

Afanasyev, K. V. and Bochantsev, V. P. 1961.The genus Achillea. In: Flora of the U.S.S.R. Vol. 26: pp. 70-124 (In Russian).

Belaeva, V. A. and Siplivinsky, V. N. 1975. Chromosome numbers and taxonomy of some species of Baikal flora. Bot. Zurn. USSR 60, 6: 864-872 (in Russian).

Bremer, K. and Humphries, C. J. 1993. Generic monograph of the Asteraceae-Anthemideae. Bull. Nat. Hist. Museum London (Bot.) 23 (2): 71-177.

Dabrowska, J. 1974. Systematic and geographic studies of the gnus Achillea L. in Poland with special reference to Silesia. Prace Bot. (Wroclaw) 24 (419): 222p.

Dmitrieva, S. A. 1987. Kariologicheskaja kharakteristika nekotorykh predstaviteley sem. Slozhnocvetnykh (Asteraceae Dumort.) flory Belorussii. Botanika (Minsk) 28: 23-33.

Goldblatt, P., Ed., 1975-2008. Chromosome numbers of the Asteraceae, Achillea and Ptarmica. Missouri Bot. Gard.,St. Louis.

Hieke, K. 1976. Pruhonicky sortiment Chrysanthemum x hortorum Bailey: vytrvale kultivary Acta Pruhoniciana 35/1976.

Hoshi, Y., Kondo, K., Konishi, T., Tannowa, T., Smirnov, S. V., Kucev, M. and Motohashi, T. 2010. A cytogenetic study in three species of Achillea. Chromosome Botany 5: 87-93.

Kartashova, N. N., Malakhova, L. A. and Kozlova, A. A. 1974. Study of the chromosomes f the representatives of 
the $\mathrm{Ob}$ region flora. I. Number of chromosomes of the Tomsk District. Dokl. Vyssh. Shk. Biol. Nauk. 4: 114-119.

Kartashova, N. N., Malakhova, L., Koslova, A. and Dubrova, N. A. 1974. Chisla chromosom u rijada polesnykh rastenij is prirodnykh populjacij flory Prib7ja. Biol. Biofis. Tomsk 47-53.

Khandzhyan, N. S. 1975. Sravnitel'noe morfologo-anatomicheskoe izuchenie semyanok Handelia I Achillea (Asteraceae). Bot. Zhurn., 69(1): 91-94.

Klokov, M. V. and Kritskaya, L. I. 1984. Systema rodiv Ptarmica Mill. and Achillea L. (=A system of the Ptarmica Mill. and Achillea L. genera) Ukr. Bot. Zhurn. 41(3): 1-11.

Krasnoborov, I. M., Krasnoborov, I. M., Lomonosova, M. N., Shaulo, D. N., Kutsev, M. G., Krasnikov, A. A.,Shmakov, A. I., German, D. A., Smirnov, S. V., Doronkin, V. M., Durnikin, D. A., Kosachev, P. A., Chubarov, L. N., Tupitsina, N. N., Usik, N. A., Silantieva, M. A., Vibe, E. I., Reviyakina, N. V., Kashina, L. I., Korolyuk, E. V., Baikov, K. S., Zhirova, O. S., Kovtonyuk, N. K., Vazhova, T. I., Priydak, N. V. and Kosterin, O. E. 2003. Ptarmica. Manual of plants in Altaiskiy Krai. Publishing House of Siberian Branch of Russian Academy of Science "Geo", Novosibirsk, pp. 631+IV (in Russian).

Lavrenko, A. N., Serditov, N. P. and Ulle, L. G. 1992. Kariologicheskie osobennosti Irasprostranenie predstavitelej semejstva Asteraceae Pechoro-Ilychskom Biosfernom Zapovednike. Trudy Komi Naucnogo Tsentra Ur.O.A.N.S.S.S.R. 126: 52-64.

Levan, A., Fredga, K., and Sandberg, A. A. 1964. Nomenclature for centromeric position on chromosomes. Hereditus 52: 201-220

Liberty Hyde Bailey Hortorium 1976. Achillea, Hortus Third. A concise dictionary of plants cultivated in the United States and Canada. Macmillan, N. Y.

Lomonosova, M. N., Shaulo, D. N., Kutsev, M. G., Krasnikov, A. A., Shmakov, A. I., German, D. A., Smirnov, S. V., Doronkin, V. M., Durnikin, D. A., .Kosachev, P. A., Chubarov, L. N., Tupitsina, N. N., Usik, N. A., Silantieva, M. A., Vibe, E. I., Revyakina, N. V., Kashina, L. I.,
Korolyuk, E. I., Antonyuk, K. S. Baikov, O. S., Zhirova, Kovtonyuk, N. K., Vazhova, T. I., Priydak, N. V, Kosterin. O. E. 2003. Ptarmica in Manual of plants in Altaiskiy Krai. pp. 415-417, Publishing House of Siberian Branch, Russian Academy of Science "Geo", Novosibirsk.

Probatova, N. S. and Sokolovskaya, A. P. 1990. Chromosome numbers in some representatives of the families Asclepiadaceae, Asteraceae, Boraginaceae, Chenopodiaceae, Lamiaceae, Oleaceae, Onagraceae, Scrophulariaceae, Solanaceae, Urticaceae from Soviet Far ast Bot. Zurn. 75: 1619-1622.

Pullariah, T. 1977. Embryology of Achillea squarrosa Ait. (Anthemideae: Compositae). Journ. Indian Bot. Soc. 62 (1):44-47.

Samutina, M. L. 1978. O sistematike vidov roda Achillea L. sektsii Ptarmicae (Mill.) Koch., rasprostranennykh v evropeiskoi chaste SSSR (=On systematic of species of genus Achillea L., section Ptarmicae (Mill.) Koch., found in the European part of the USSR) Vestn. Leningrad. Univ., Biol., no. 21: 95-97.

Shih, C. and Fu, G. 1983. Compositae, 7. Tribe Anthemideae Cass. Flora, Reipublicae Popularis Sinicae. 76 (1), Science Press, Cinese Academy of Science, Beijing, pp. 149.

Schaulo, M. N. D. 2003. Keys to plants of the Altai Territory.Novosibirsk, Russian Academy of Sciences Publisher, "Geo". - P. 393-471 (in Russian).

Sokolovskaya, A. P. and Probatova, N. S. 1985. Chromosome numbers in the vascular plants from the Pryimorye Territory, Kamchatka region, Amur Valley and Sakhalin. Bot. Zurn. SSSR. 70(7): 997-999 (in Russian).

Tril', V. M. 1979. Rasprostranenie I zapasy podorozhnika bol'shogo bol'shogo I tysyachelistnika obyknovennogo v Novosibirskoi oblasti. (Distribution and reserves of Plantago major and Achillea millefolium in Novosibirsk Rgion). Izv.Sibir. Otdel, Akad. Nauk. Biol. Nauk 15(3): 64-66.

Zhukova, P. G. and Petrovsky, V. V. 1987.Chromosome numbers and taxonomy of some plant species from the southern Asia regions. Bot. Zurn. 72: 1617-1624. 